\title{
STUDIES OF URIC ACID POOL SIZE AND TURNOVER RATE*
}

\author{
BY \\ J. T. SCOTT, V. P. HOLLOWAY, H. I. GLASS, AND R. N. ARNOT \\ Departments of Rheumatology and Medical Physics, Royal Postgraduate \\ Medical School, Hammersmith Hospital, London
}

Labelled uric acid can be used to estimate the exchangeable pool size and turnover of uric acid in man. Benedict, Forsham, and Stetten (1949), Geren, Bendich, Bodansky, and Brown (1950), and Bishop, Garner, and Talbott (1951) used nitrogen-15 labelled uric acid: carbon-14 labelled uric acid has been used by Sørensen (1960) and by Seegmiller, Grayzel, Laster, and Liddle (1961), who discussed some of the possible limitations of the technique in relation to other mehods of assessing urate biosynthesis and disposition.

Pool size is usually estimated by extrapolation to zero time of the curve obtained by plotting the logarithm of the relative specific activity of uric acid

- This paper was presented at a meeting of the Heberden Society in March 1968. Requests for reprints should be addressed to Dr. J. T. Scott, Charing Cross Hospital, London, W.C.2. in the urine against time and by assuming that this curve is monoexponential, i.e. a straight line. Bishop and others (1951), however, indicated that several of their curves and of those obtained by Benedict and others (1949) were not straight when plotted in this way, and this finding was confirmed by Sørensen (1960). Bishop and others (1951) analysed the curves empirically into two exponential components in order to extrapolate more accurately to zero time. Sørensen (1962) found that, whereas the decline of logarithm isotope concentration in urinary uric acid formed a straight line in the case of a normal subject and of a patient with nontophaceous gout, the line was curved in the case of a patient with chronic tophaceous gout, due perhaps to a continuous process of dissolution and precipitation of uric acid at those areas of tophi in contact with the body fluids; and he proposed a

DETAILS OF NINETEEN

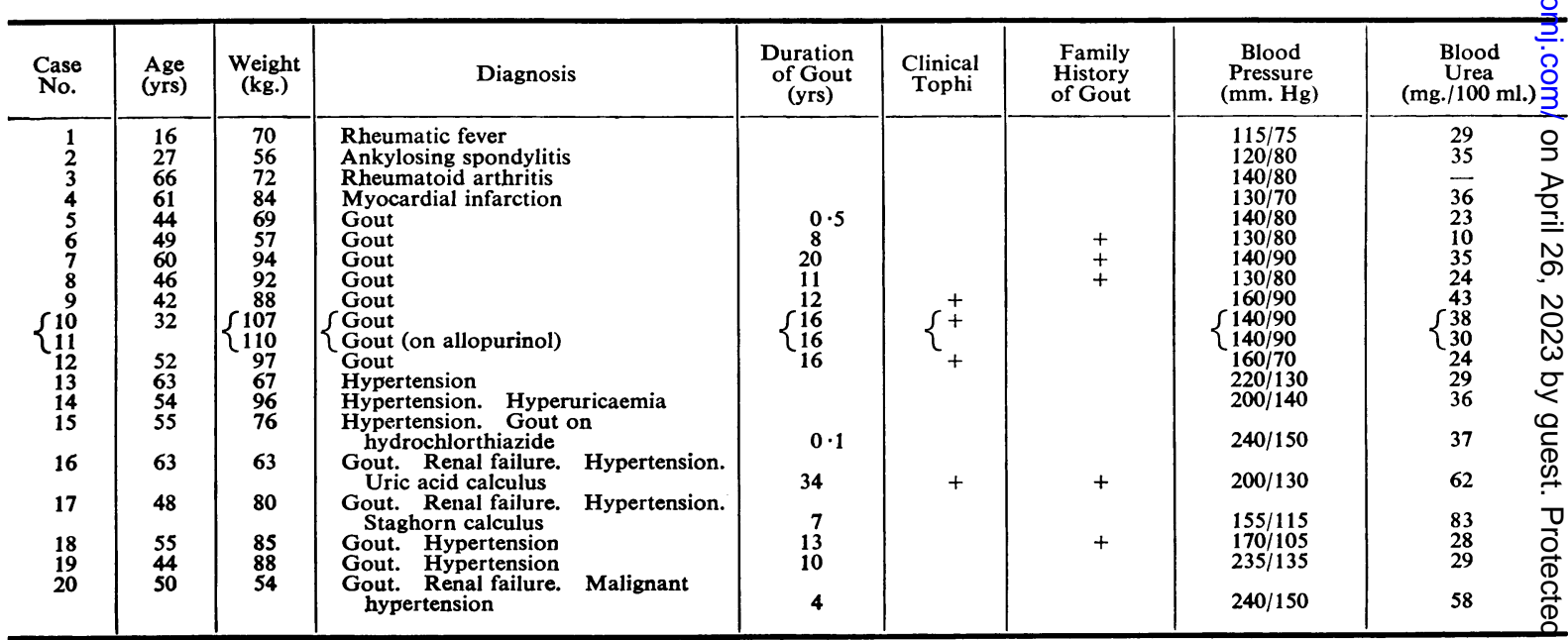

* One compartment model useg 
two-compartment system to account for this phenomenon. However, Bishop and others (1951) observed that curved rather than straight lines were not confined to patients with tophaceous gout.

Several problems are thus posed, not the least of which is how to determine the optimum method of analysing the data. If a mathematically significant improvement in fit is obtained by analysing data in terms of a double rather than of a single exponential mathematical function, a method of estimating pool size and turnover rate in this situation is required.

\section{(1) Patients Studied}

\section{Methods}

Details are presented in Table I. Twenty investigations using uric acid-2-14 $\mathrm{C}$ were carried out upon nineteen adult subjects, all hospital inpatients. Five of these (with rheumatoid arthritis, rheumatic fever, convalescent myocardial infarction, ankylosing spondylitis, and essential hypertension) had serum uric acid levels of under $6.0 \mathrm{mg}$. $/ 100 \mathrm{ml}$.; one, the only female in the series, had essential hypertension with a mean serum uric acid level of $6.6 \mathrm{mg}$. $/ 100 \mathrm{ml}$. (Case 14); nine had primary gout with no clinical evidence of tophus formation; and four had chronic tophaceous gout. One of the last patients was studied twice, i.e. before and after 9 months' continuous treatment with allopurinol; the findings are given as Cases 10 and 11.

\section{(2) Regimen}

No patients received uricosuric or antihypertensive therapy during the period of study, although a few were taking low maintenance doses of colchicine. Case 11 was maintained on $600 \mathrm{mg}$. allopurinol daily throughout the second period of study.

Patients were placed on a low purine, low protein diet (National Institutes of Health, Bethesda, low purine diet: daily purine content approximately $200 \mathrm{mg}$.) for a preliminary period of not less than 7 days to allow the serum and urinary uric acid levels to reach a steady state, and they were maintained on this diet during the experimental period.

At zero time, the patient voided urine and a base line blood sample was taken. $30 \mu \mathrm{c}$. uric acid-2-14 $\mathrm{C}$ were injected intravenously over a period of 10 minutes. Blood samples were collected at increasing intervals for 11 days. Serum was separated, assayed for uric acid content, and frozen at $-20^{\circ} \mathrm{C}$. Urine was collected under toluene in six 12-hourly periods followed by eight 24-hourly periods, care being taken to ensure that each patient emptied his bladder at the end of every collection period. Urines were assayed for uric acid content and uric acid-2-14C was extracted.

\section{(3) Isotope Methods}

\section{(i) Preparation of Intravenous Solution}

$100 \mu \mathrm{c}$. uric acid-2.14 $\mathrm{C}$ of specific activity between 0.05 and $0.12 \mathrm{mc} . / \mathrm{mg}$. were completely dissolved in $100 \mathrm{ml}$. isotonic saline by heating. The solution was not allowed to boil. After cooling, $50 \mathrm{ml}$. were injected into a sealed sterile bottle through an $0 \cdot 22 \mu$ Millipore filter, and the solution was used immediately. After the completion of the injection, aliquots were assayed for uric acid content and standards for urine counting were prepared.

(ii) Preparation of Urine Standards

Two standards were prepared by diluting $1.0 \mathrm{ml}$. of the dose solution to $100 \mathrm{ml}$. 5 and $15 \mathrm{ml}$. aliquots of this

I I

PATIENTS STUDIED

\begin{tabular}{|c|c|c|c|c|c|c|}
\hline $\begin{array}{l}\text { Glomerular } \\
\text { Filtration Rate } \\
\text { (ml./min.) }\end{array}$ & 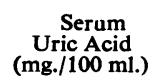 & $\begin{array}{c}\text { Urinary } \\
\text { Uric Acid } \\
\text { (mg./24 hrs) }\end{array}$ & $\begin{array}{l}\text { Uric Acid } \\
\text { Clearance } \\
\text { (ml./min.) }\end{array}$ & $\begin{array}{c}\text { Total } \\
\text { Exchangeable Pool } \\
\text { (mg.) }\end{array}$ & $\begin{array}{c}\text { Turnover } \\
\text { Rate } \\
\text { (mg. } / 24 \mathrm{hrs} \text { ) }\end{array}$ & $\begin{array}{l}\text { No. of } \\
\text { Components }\end{array}$ \\
\hline $\begin{array}{r}\overline{88} \\
\overline{-} \\
\overline{77} \\
\frac{88}{134} \\
\frac{1}{125} \\
99 \\
92\end{array}$ & $\begin{array}{r}4 \cdot 2 \pm 0 \cdot 5 \\
4 \cdot 5 \pm 0 \cdot 3 \\
5 \cdot 3 \pm 0 \cdot 5 \\
5 \cdot 9 \pm 0 \cdot 5 \\
7 \cdot 1 \pm 0 \cdot 5 \\
7 \cdot 2 \pm 1 \cdot 0 \\
7 \cdot 5 \pm 1 \cdot 0 \\
6 \cdot 6 \pm 0 \cdot 9 \\
9 \cdot 4 \pm 1 \cdot 2 \\
9 \cdot 9 \pm 1 \cdot 3 \\
3 \cdot 4 \pm 0.6 \\
10 \cdot 4 \pm 1 \cdot 7 \\
5.7 \pm 0.7 \\
6 \cdot 6 \pm 0 \cdot 3\end{array}$ & $\begin{array}{c}430+206 \\
391 \pm 113 \\
365 \pm 161 \\
370 \pm 170 \\
487 \pm 67 \\
251 \pm 130 \\
341 \pm 84 \\
440 \pm 296 \\
691 \pm 180 \\
550 \pm 240 \\
177 \pm 48 \\
680 \pm 295 \\
346 \pm 78 \\
300 \pm 77\end{array}$ & $\begin{array}{r}7 \cdot 2 \pm 3 \cdot 6 \\
6 \cdot 1 \pm 1 \cdot 9 \\
4 \cdot 5 \pm 1 \cdot 4 \\
4 \cdot 4 \pm 2 \cdot 1 \\
4 \cdot 8 \pm 0.9 \\
2 \cdot 5 \pm 1 \cdot 5 \\
3 \cdot 2 \pm 0 \cdot 8 \\
4 \cdot 7 \pm 0 \cdot 3 \\
5 \cdot 11 \pm 1 \cdot 4 \\
3 \cdot 9 \pm 2 \cdot 0 \\
3 \cdot 5 \pm 1 \cdot 3 \\
4 \cdot 6 \pm 2 \cdot 4 \\
4 \cdot 2 \pm 0 \cdot 8 \\
3 \cdot 2 \pm 0.9\end{array}$ & $\begin{array}{c}1,081+41 \\
1,019 \pm 26 \\
992 \pm 37 \\
1,650 \pm 47 \\
1,388 \pm 20 \\
1,324 \pm 22 \\
1,928 \pm 34 \\
1,933 \pm 49 \\
2,475 \pm 68 \\
2,471 \pm 138 \\
1,031 \pm 36 \\
3,199 \pm 1,477 \\
1,362 \pm 18 \\
1,742 \pm 52\end{array}$ & $\begin{array}{c}795 \pm 43 \\
723 \pm 36 \\
602 \pm 32 \\
838 \pm 35 \\
789 \pm 38 \\
659 \pm 16 \\
771 \pm 21 \\
1,000 \pm 55 \\
1,149 \pm 45 \\
\{861 \pm 585 \\
314 \pm 15 \\
948 \pm 115 \\
552 \pm 11 \\
650 \pm 27\end{array}$ & $\begin{array}{l}1 \\
1 \\
1 \\
2^{*} \\
2 \\
1 \\
2^{*} \\
2 \\
2^{*} \\
2 \\
1 \\
2 \\
2 \\
1\end{array}$ \\
\hline - & $6 \cdot 9 \pm 1 \cdot 0$ & $279 \pm 73$ & $2 \cdot 8 \pm 0.7$ & $1,284 \pm 64$ & $506 \pm 35$ & 1 \\
\hline 54 & $10 \cdot 9 \pm 0 \cdot 5$ & $963 \pm 134$ & $6 \cdot 7 \pm 1 \cdot 0$ & $1,948 \pm 23$ & $1,542 \pm 70$ & 2 \\
\hline $\begin{array}{l}17 \\
78\end{array}$ & $\begin{array}{l}9 \cdot 9 \pm 0 \cdot 5 \\
7 \cdot 9 \pm 0 \cdot 6 \\
7 \cdot 0 \pm 0 \cdot 5\end{array}$ & $\begin{array}{l}417 \pm 80 \\
519 \pm 113 \\
353 \pm 64\end{array}$ & $\begin{array}{l}2 \cdot 9 \pm 0 \cdot 5 \\
4 \cdot 6 \pm 1 \cdot 1 \\
3 \cdot 5 \pm 0 \cdot 6\end{array}$ & $\begin{array}{l}2,933 \pm 71 \\
1,943 \pm 35 \\
1,569 \pm 49\end{array}$ & $\begin{array}{l}939 \pm 32 \\
802 \pm 22 \\
616 \pm 27\end{array}$ & $\begin{array}{l}2 * \\
2^{*} \\
1\end{array}$ \\
\hline 22 & $9 \cdot 2 \pm 0 \cdot 6$ & $261 \pm 30$ & $2 \cdot 0 \pm 0 \cdot 3$ & $2,282 \pm 53$ & $824 \pm 27$ & 1 \\
\hline
\end{tabular}


diluted solution were added to $250 \mathrm{mg}$. inactive uric acid which had been dissolved in $10 \mathrm{ml} .0 .73$ per cent. (w/v) lithium carbonate. The final volume was made up to $35 \mathrm{ml}$. with distilled water. The tubes were placed in a boiling water bath and the uric acid reprecipitated by the dropwise addition of $2.0 \mathrm{~N}$ acetic acid. After cooling to room temperature, the precipitated uric acid was collected in a sintered glass funnel and washed with distilled water until the eluate was neutral. The crystals were dried overnight at $80^{\circ} \mathrm{C}$. and stored in a desiccator until assayed. Any breakdown products of uric acid in the dose solution which were produced during its preparation were thus eliminated, and the immediate preparation of the standards ensured that no significant breakdown of the uric acid could occur in the dose solution since the time of the injection.

\section{(iii) Preparation of Urine Samples}

Aliquots of known volume, increasing from 10 to $200 \mathrm{ml}$. over the period of the investigation, were removed from the 12 - and 24-hour collections. $250 \mathrm{mg}$. inactive uric acid were added to each sample which was then processed by the method of Sørensen (1960).

\section{(iv) Counting Technique}

Approximately $25 \mathrm{mg}$. pure uric acid extracted by this method were weighed into counting vials and, after gentle tapping of the vials to break up any accumulations of uric acid crystals, $20 \mathrm{ml}$. scintillator gel (Helf, White, and Shelley, 1960) were added by pipette. The vials were shaken vigorously to disperse the suspension evenly, cooled at $4^{\circ} \mathrm{C}$., and counted in an automatic liquid scintillation counter. Duplicates were made of at least four samples. Two $25-\mathrm{mg}$. samples of each standard were prepared in the same way and two background samples of $20 \mathrm{ml}$. gel were used. A total of 30,000 counts were obtained from the majority of samples, the lowest number of counts being 7,000 when the sample to background ratio was $7: 1$. The percentage of the injected dose contained in each standard sample and the weight of uric acid originating from urine in each sample was calculated. The percentage of the dose per mg. uric acid in each urine collection was then determined and the results plotted against the midtime collection period.

\section{(v) Assay of Total Serum Activity}

A standard solution was made by diluting $1.0 \mathrm{ml}$. of the dose solution to $500 \mathrm{ml}$. Duplicate serum, standard and background samples were prepared by adding $1.0 \mathrm{ml}$. serum, standard solution, and inactive serum respectively to $10 \mathrm{ml}$. scintillator (Bray, 1960). The samples were shaken and left for 3 hours for the protein precipitate to settle. They were then cooled for 20 minutes at $4^{\circ} \mathrm{C}$. and counted in an automatic liquid scintillation counter. 10,000 counts were obtained in samples taken up to 2 days and the total counts decreased to a minimum of 1,000 for the last sample. Internal standards were added and the samples reshaken, allowed to stand for 3 hours and cooled before recounting. The percentage of the dose per mg. uric acid in each serum sample was calculated and the results plotted against the time of sampling.

\section{(4) Chemical Methods}

The concentration of uric acid in serum, urine and the solutions prepared for intravenous injection was determined by a slightly modified version of the uricase method of Praetorius (1949). Glomeruler filtration rate was measured by creatinine clearance (Owen, Iggo, Scandrett, and Stewart, 1954). Blood urea was determined by a standard Auto-analyzer technique, using diacetyl monoxime.

\section{(5) Data Analysis}

The urine data were analysed using the Gilles exponential curve fitting programme (Gilles and Ben Hameid, 1966) to determine the number of exponentials, and the Berman model fitting programme (Berman, Shahn, and Weiss, 1962) to calculate the pool sizes and errors in the parameters. In five of the eleven patients whose data were mathematically better fitted by two exponentials, the Berman programme indicated excessive parameter errors, and for these patients the pool sizes in Table I were therefore calculated using a one compartment model. The analysis procedures used to obtain the results in Table I have been described in detail (Glass, Scott, Gilles, Arnot, Holloway, and Ben Hameid, 1968).

\section{Results}

\section{(1) Exponential Components}

Table I shows that all four patients with tophaceous gout (Cases 9, 10, 12, and 16) showed two exponential components. However, two exponential components were also indicated in seven other subjects. Of these, five (Cases 5, 7, 8, 17, and 18) had gout, four of them (Cases 7, 8, 17, and 18) with histories ranging from 7 to 20 years and with possible radiological evidence of solid urate deposition. The gout in Case 5, however, was of only 5 months' duration, and two exponential components were also found in Cases 4 and 13-patients with myocardial infarction and hypertension respectively with no evidence of gout. The curves from Cases 16 and 14 are shown in Fig. 1. In the data from
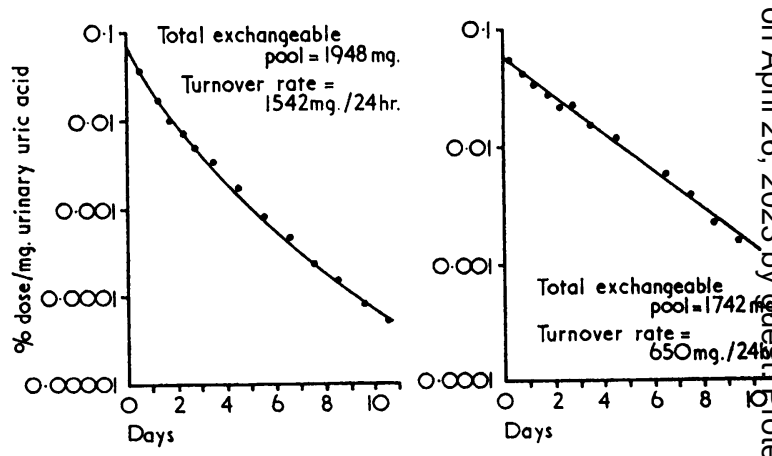

Fig. 1.-Decline of logarithm isotope concentration in urinary uric acid in Case 16 and Case 14. The former is curved, indicating the presence of more than one exponential component; the second is a straight line, indicating a single exponential component. 
five patients the Gilles programme indicated that two exponentials fitted the data best and the error estimates obtained by the Berman programme were not considered excessive. In these five patients, the presence of two pools is highly probable. The size of each compartment, the transfer rates between the compartments, and the errors in these quantities are presented in Table II.

\section{(2) Pool Size and Turnover Rate}

The mean exchangeable pool size for the five subjects with a normal serum uric acid level (Cases $1,2,3,4$, and 13, but excluding Case 11 with treated gout) was $1,221 \mathrm{mg}$. (range 992 to 1,650 ); while that of the other patients, with gout and/or hyperuricaemia, was $2,027 \mathrm{mg}$. (range 1,248 to $3,199)$. The mean turnover rate for the normal group was $701 \mathrm{mg} . / 24$ hours (range 602 to 838). The mean rate for the other patients was $861 \mathrm{mg}$. (range 506 to 1,542). Taking the results from all the twenty studies, there was a significant tendency for the higher pool sizes to correlate with higher turnover rates $(r=0.56 ; \mathrm{P}<0.005)$. Serum and urinary uric acid figures are also shown in Table $I$. For the five subjects with a normal serum uric acid (less than $6.0 \mathrm{mg} . / 100 \mathrm{ml}$.) the mean urinary excretion was $380 \mathrm{mg} . / 24 \mathrm{hrs}$ (range 346-430). The mean urinary excretion of the other patients with gout or hyperuricaemia was $466 \mathrm{mg} . / 24 \mathrm{hrs}$ (range 251-963).

\section{(3) Relation of Pool Size to Serum Uric Acid Level}

This is shown for the twenty cases in Fig. 2. There is a significant correlation between these parameters $(r=0 \cdot 8823 ; \mathrm{P}<0 \cdot 001)$.

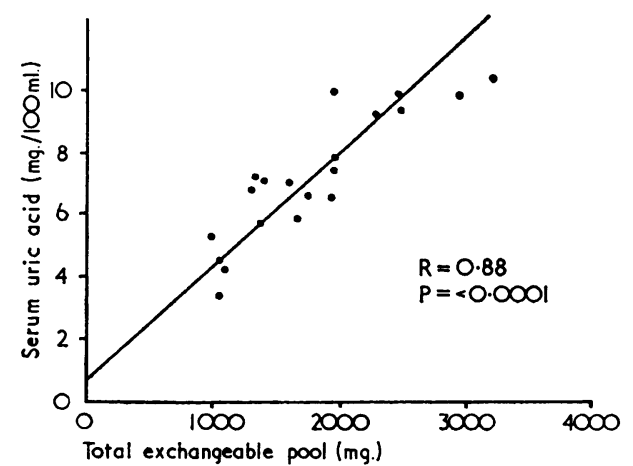

Fig. 2.-Relation of pool size to serum unic acid level.

(4) Relation of Turnover Rate to Urinary Uric Acid

Again there is a correlation (Fig. 3). As far as renal function was estimated in these patients, this appeared to be normal in all subjects except Case 16 (blood urea $62 \mathrm{mg}$. $/ 100 \mathrm{ml}$.; glomerular filtration rate (GFR) $54 \mathrm{ml} . / \mathrm{min}$.), Case 20 (blood urea

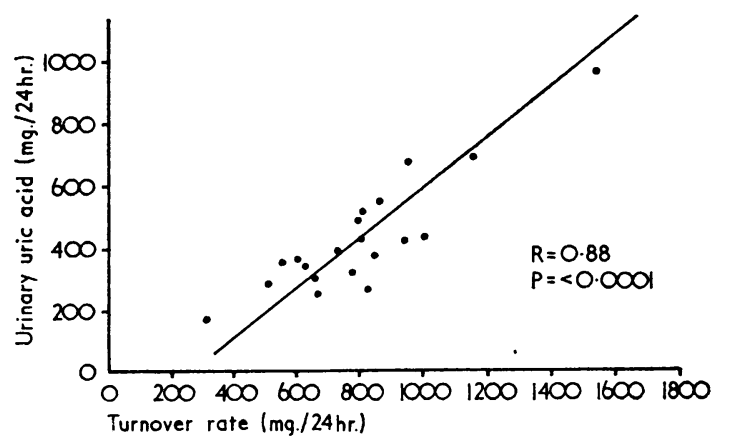

Fig. 3.-Relation of turnover rate to urinary uric acid.

TABLE II

TWO COMPARTMENT MODEL POOL SIZES, TURNOVER AND TRANSFER RATES

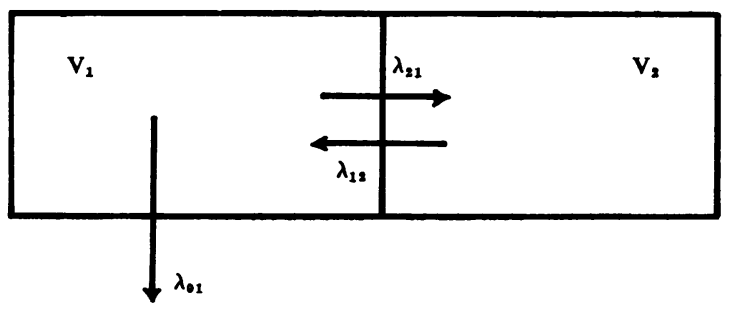

\begin{tabular}{|c|c|c|c|c|}
\hline $\begin{array}{l}\text { Patient } \\
\text { No. }\end{array}$ & $\underset{(\mathrm{mg} .)}{\operatorname{Pool~Size}\left(\mathrm{V}_{1}\right)}$ & $\underset{\text { (mg.) }}{\text { Pool Size }}\left(\mathrm{V}_{2}\right)$ & $\underset{\text { (mg./day) }}{\text { Turnover Rate }}\left(\lambda_{01} \cdot V_{1}\right)$ & $\begin{array}{c}\text { Transfer Rate between Compartments } \\
\left(\lambda_{12} \mathrm{~V}_{2}, \lambda_{21} \mathrm{~V}_{1}\right) \\
(\mathrm{mg} / \mathrm{day})\end{array}$ \\
\hline $\begin{array}{r}5 \\
8 \\
12 \\
13 \\
16\end{array}$ & $\begin{array}{l}1,076 \pm 35 \\
1,736 \pm 66 \\
1,975 \pm 208 \\
1,227 \pm 17 \\
1,606 \pm 46\end{array}$ & $\begin{array}{c}312 \pm 32 \\
197 \pm 64 \\
1,224 \pm 1,283 \\
135 \pm 15 \\
342 \pm 35\end{array}$ & $\begin{array}{c}789 \pm 38 \\
1,000 \pm 55 \\
948 \pm 115 \\
552 \pm 11 \\
1,542 \pm 70\end{array}$ & $\begin{array}{c}390 \pm 101 \\
148 \pm 114 \\
195 \pm 39 \\
77 \pm 21 \\
329 \pm 76\end{array}$ \\
\hline
\end{tabular}


$58 \mathrm{mg} . / 100 \mathrm{ml}$; GFR $22 \mathrm{ml} . / \mathrm{min}$.) and Case 17 (blood urea $83 \mathrm{mg} . / 100 \mathrm{ml}$.; GFR $17 \mathrm{ml} . / \mathrm{min}$.). Despite this disturbance of GFR, the relationship between turnover rate and urinary uric acid in those three subjects was similar to that of patients with normal renal function, although in Case 20 the mean 24-hr urinary uric acid excretion was relatively low (261 mg.) compared with the turnover rate of $824 \mathrm{mg} . / 24 \mathrm{hrs}$.

(5) Effect of Allopurinol on Number of Compartments, Pool Size, and Turnover Rate

One subject was studied before (Case 10) and after (Case 11) treatment with the xanthine oxidase inhibitor allopurinol. Before treatment a twocompartment system was indicated but after 9 months of treatment with allopurinol $600 \mathrm{mg}$. daily (during which a small tophus on one elbow, from which urate crystals had been removed, disappeared) only a single compartment system was shown (Fig. 4). The serum uric acid fell from $9.9 \mathrm{mg} . / 100 \mathrm{ml}$. before treatment to $3.4 \mathrm{mg}$. $/ 100 \mathrm{ml}$. after 9 months' treatment. The pool size fell from 2,471 to 1,031 mg., the 24-hr urinary uric acid from 550 to $172 \mathrm{mg}$., and the daily turnover rate from 861 to $314 \mathrm{mg}$.

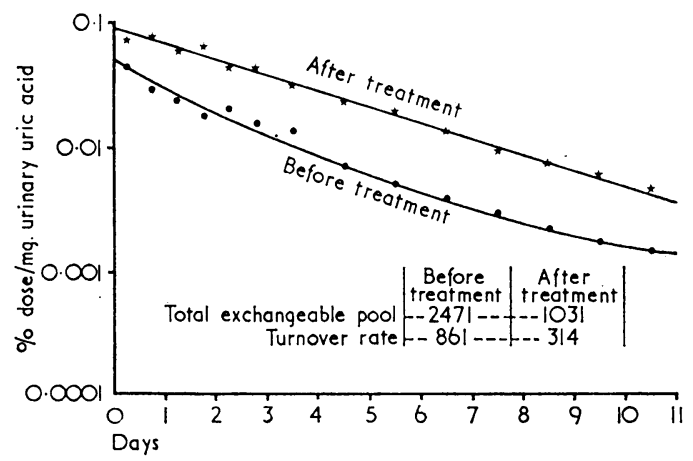

Fig. 4.-Decline in logarithm isotope concentration in urinary uric acid in one patient before (Case 10) and after 9 months (Case 11) t1 eatment with allopurinol.

\section{(6) Hypertension}

Eight patients in this study had a raised blood pressure (Cases 13, 14, 15, 16, 17, 18, 19, and 20) and of these, all but two (Cases 13 and 14) had gout. The relationship between hypertension, impairment of renal function, hyperuricaemia, and gout is incompletely understood, and it is often impossible to trace the sequence of events in individual patients. However, there are some differences between the patients in this group. Cases 13 and 14 did not have gout and the serum uric acid level in Case 13 was normal although rather high in Case 14. Case
15 had been known to be hypertensive since 1947 but did not have his first attack of gout until 1965 at which time he was taking hydrochlorthiazide and his serum uric acid was $9.4 \mathrm{mg} . / 100 \mathrm{ml}$. In these patients, a raised blood pressure appeared to be the predominant disorder.

In contrast the onset of gout in Cases 16 and 17 was known to precede that of hypertension and there was a family history of gout. In Case 18, there was also a long history of gout with a positive family history and, although his previous blood pressure was unknown, it was only moderately raised at the time of study.

Case 19 had a 10-year history of gouty arthritis and when first seen was severely hypertensive, while Case 20 was known to have a normal blood pressure in 1955, developed recurrent acute gouty arthritis in 1961, and rapidly developed malignant hypertension with papilloedema in 1963 (which responded to treatment with Guanethidine). In these last two patients, the relation between the gout and hypertension is quite obscure. In none of Cases 13, 14, 15,19 , and 20 was there a family history of gout. Turnover rates in Cases 16, 17, and 18, in whom there is good evidence of primary gout, were higher than in Cases 13, 14, and 15 in whom essential hypertension appeared to be the primary disorder.

\section{(7) Serum Radioactivity}

The possibility of obtaining reliable estimates of pool size and turnover rates from radioactivity measurements in the serum was investigated in thirteen patients. Serum concentration was measured in samples taken between Days 2 and 9 inclusive. These limits were taken, after inspection of the serum clearance curves, to minimize any second pool effects by eliminating the values taken before Day 2; and to minimize the effect of breakdown products of uric acid in the serum by omitting data taken after Day 9. A monoexponential function was fitted to these data and the pool sizes and turnover rates were estimated.

Results are compared with those obtained from calculations based on urine data in Table III. There is a very high correlation $(0.96)$ between the same quantities estimated by the different methods, but the standard error of the estimates are $12 \cdot 3$ and 19.6 per cent. for pool size and turnover rate respectively.

\section{Discussion}

Obvious difficulties arise in interpreting the radioactive uric acid clearance in terms of pool size and turnover rates when the clearance curve is not monoexponential. In general, attempting to treat 
TABLE III

COMPARISON OF POOL SIZE AND TURNOVER ESTIMATED FROM URINE AND SERUM

\begin{tabular}{|c|c|c|c|c|}
\hline \multirow{2}{*}{ Case No. } & \multicolumn{2}{|c|}{ Pool Size (mg.) } & \multicolumn{2}{|c|}{ Turnover (mg./day) } \\
\hline & Urine & Serum & Urine & Serum \\
\hline \multirow[t]{2}{*}{$\begin{array}{r}1 \\
6 \\
7 \\
8 \\
9 \\
10 \\
12 \\
13 \\
14 \\
17 \\
18 \\
19 \\
20\end{array}$} & $\begin{array}{l}1,081 \\
1,324 \\
1,928 \\
1,933 \\
2,475 \\
1,031 \\
3,199 \\
1,362 \\
1,742 \\
2,933 \\
1,943 \\
1,569 \\
2,282\end{array}$ & $\begin{array}{r}975 \\
1,804 \\
2,421 \\
1,668 \\
3,084 \\
1,474 \\
4,006 \\
1,446 \\
1,455 \\
3,092 \\
3,044 \\
1,570 \\
2,689\end{array}$ & $\begin{array}{r}795 \\
659 \\
771 \\
1,000 \\
1,149 \\
314 \\
948 \\
552 \\
650 \\
939 \\
802 \\
616 \\
824\end{array}$ & $\begin{array}{r}906 \\
837 \\
968 \\
938 \\
1,545 \\
392 \\
1,735 \\
665 \\
611 \\
1,014 \\
893 \\
631 \\
789\end{array}$ \\
\hline & \multicolumn{2}{|c|}{$\begin{array}{l}\text { Standard error of } \\
\text { Estimate }=12 \cdot 3 \text { per cent. } \\
\text { on serum measurement }\end{array}$} & \multicolumn{2}{|c|}{$\begin{array}{l}\text { Standard error of } \\
\text { Estimate }=19 \cdot 6 \text { per cent. } \\
\text { on serum measurement }\end{array}$} \\
\hline
\end{tabular}

such data as a monoexponential function will yield an overestimate of the first pool size and hence of the turnover rate. In most cases no significant errors will be introduced but in cases associated with large pools and high turnover rates the errors may be 20 per cent. or more. This is the difference in the estimate of both pool size and turnover rate if the data from the Patient 16, for example, are analysed first as a monoexponential function and then as a double exponential function.

The existence of a second pool of exchangeable uric acid in a physiologically different form from that of the first pool is probable in a number of patients studied, most of whom had gout, some with definite clinical tophi. It is reasonable to suppose that such a second pool represents the exchangeable surface of tophaceous deposits or crystalline microtophi. In this respect the two studies (10 and 11) carried out on the same patient before and after 9 months' treatment with allopurinol are of particular interest. At the time of the first study the patient was having severe gouty arthritis and he had a small tophus on one elbow: this was associated with evidence of a second pool. During treatment attacks of acute gout ceased, the tophus disappeared, and the second study indicated the presence of a smaller single pool only. It is conceivable that the two-compartment analysis procedure could provide a method of estimating quantitatively the exchangeable uric acid associated with tophi or microtophi. However, not all the patients with evidence of two pools had gout.

Mean values of exchangeable pool size and daily turnover rates for control subjects with a normal serum uric acid level compare moderately well with those obtained by previous workers, considering the small numbers involved in all the series (Table IV). The exchangeable pool size was higher in patients with gout or hyperuricaemia, some of whom had turnover rates within the normal range, some in excess.

There is a significant association between the level of serum uric acid and the exchangeable pool size in the range of values shown by the patients studied. This may not be valid in subjects with very high pool sizes and perhaps where there is acute elevation of the serum uric acid, although we have no information on this. There is a similar correlation between urinary uric acid and turnover rate. It has been stressed (Sørensen, 1960) that urinary urate cannot be used as a direct measure of total uric acid production, largely on account of extrarenal disposal of urate. The cumulative recovery of urate in the present study was in the region of 60 per cent., a figure much in accordance with those of others, but it is nevertheless clear that urinary uric acid does provide some index of uric acid production. In patients with severe renal failure, urinary excretion will be low despite a high turnover rate; however, Pollard (1968) has shown that in renal failure the serum uric acid level does not tend to rise until the GFR falls to about $20 \mathrm{ml}$./ min., implying that with lesser degrees of impairment there is little decrease in urinary uric acid excretion. Three subjects in the present study, Cases 16, 17, and 20, had impaired GFRs of 54, 17, and $22 \mathrm{ml} . / \mathrm{min}$. respectively, but their urinary uric acid when plotted against turnover rate lay fairly close to the general regression line shown in Fig. 3.

These correlations are also seen in the other studies to which reference has been made. Thus analysis

TABLE IV

MEAN VALUES OF EXCHANGEABLE POOL SIZE AND DAILY TURNOVER RATE IN CONTROL SUBJECTS

\begin{tabular}{|c|c|c|c|}
\hline & $\begin{array}{l}\text { No. of } \\
\text { Subjects }\end{array}$ & $\begin{array}{c}\text { Exchangeable Pool } \\
\text { (mg.) }\end{array}$ & $\begin{array}{l}\text { Turnover } \\
\text { (mg./24 hrs) }\end{array}$ \\
\hline $\begin{array}{l}\text { Benedict and others (1949) } \\
\text { Bishop and others (1951) } \\
\text { Buzard, Bishop, and Talbot (1952) } \\
\text { Serensen (1960, 1962) } \\
\text { Seegmiller and others (1961) } \\
\text { Present series }\end{array}$ & $\begin{array}{l}3 \\
3 \\
3 \\
3 \\
7 \\
\mathbf{5}\end{array}$ & $\begin{array}{l}1,220(1,145-1,341) \\
1,060(937-1,228) \\
1,164(1,072-1,253) \\
1,308(1,247-1,352) \\
1,071(946-1,290) \\
1,221(992-1,650)\end{array}$ & $\begin{array}{l}758(715-867) \\
885(800-1,016 \\
849(766-942) \\
662(625-699) \\
622(593-729) \\
701(602-838)\end{array}$ \\
\hline
\end{tabular}


of the data of Seegmiller and others (1961) confirms a relation between serum uric acid and exchangeable pool size $(r=0.91 ; \mathrm{P}<0.001)$ for non-tophaceous subjects. When tophaceous subjects are included, the relationship is not so close but calculations in this study were based on a monoexponential rate of decline, whereas, as indicated above, it is possible that a double exponential analysis may have been more relevant in these subjects.

Of the eight patients with hypertension (seven of whom were hyperuricaemic) only one showed a clear increase in turnover rate. This was Case 16, in whom there was definite evidence of primary gout with later hypertension. The patients with essential hypertension all had a low turnover rate, which accords with the finding of Breckenridge (1966) who demonstrated that the hyperuricaemia often found in patients with hypertension is due to impaired excretion associated with an abnormality in tubular handling of uric acid.

Calculation of pool size and turnover rates from serum radioactivity showed a clear correlation with values obtained from urine, but the standard error of the estimates were 12.3 and 19.6 per cent. for pool size and turnover rate respectively. This would imply that the application of serum results in a particularly individual is less useful than a study performed by analysis of urine samples.

\section{Summary}

The excnangeable pool and turnover rate of uric acid has been determined in nineteen subjects, some with gout and some without, using ${ }^{14} \mathrm{C}$-labelled uric acid.

In some cases a mathematically significant improvement in fit was obtained by describing urinary radioactive uric acid clearance curves with a double exponential rather than with a monoexponential function. In such cases it is suggested that urate may exist in a second physiological pool, perhaps in relation to the surface of tophi or crystalline microtophi. One patient showed a double exponential curve before treatment and a monoexponential curve nine months after starting treatment with allopurinol, implying the disappearance of a second pool.

There is a significant relation between pool size and the level of serum urate and between turnover rate and urinary urate excretion.

The accuracy with which pool size and turnover rate may be estimated from serum measurements has also been investigated.

\section{REFERENCES}

Benedict, J. D., Forsham, P. H., and Stetten, D., Jr. (1949). J. biol. Chem., 181, 183 (The metabolism of uric acid in the normal and gouty human studied with the aid of isotopic uric acid).

Berman, M., Shahn, E., and Weiss, M. F. (1962). Biophys. J., 2, 275 (The routine fitting of kinetic data to models: a mathematical formalism for digital computers).

Bishop, C., Garner, W., and Talbott, J. H. (1951). J. clin. Invest., 30, 879 (Pool size, turnover rate, and rapidity of equilibration of injected isotopic uric acid in normal and pathological subjects).

Bray, G. A. (1960). Analyt. Biochem., 1, 279 (A simple efficient liquid scintillator for counting aqueous solutions in a hiquid scintillation counter).

Breckenridge, A. (1966). Lancet, 1, 15 (Hypertension and hyperuricaemia).

Buzard, J., Bishop, C., and Talbott, J. H. (1952). J. biol. Chem., 196, 179 (Recovery in humans of intravenously injected isotopic uric acid).

Geren, W., Bendich, A., Bodansky, O., and Brown, G. B. (1950). Ibid., 183, 21 (The fate of uric acid in man).

Gilles, D. C., and Ben Hameid, S. S. (1966). Personal communication.

Glass, H. I., Scott, J. T., Gilles, D. C., Arnot, R. N., Holloway, V. P., and Ben Hameid, S. S. (1968). Radioakt. Isotope Klin. Forsch., 8, 223 (The interpretation of radioactive uric acid turnover data).

Helf, S., White, C. G., and Shelley, R. N. (1960). Analyt. Chem. (Wash.), 32, 238 (Radioassay of finely divided solids by suspension in a gel scintillator).

Owen, J. A., Iggo, B., Scandrett, F. J., and Stewart, C. P. (1954). Biochem. J., 58, 426 (The determination of creatinine in plasma or serum and in urine; a critical examination).

Pollard, A. C. (1968). Personal communication.

Praetorius, E. (1949). Scand. J. clin. Lab. Invest., 1, 222 (An enzymatic method for the determination of uric acid by ultraviolet spectrophotometry).

Seegmiller, J. E., Grayzel, A. I., Laster, L., and Liddle, L. (1961). J. clin. Invest., 40, 1304 (Uric acid production in gout).

Sørensen, L. B. (1960). Scand. J. clin. Lab. Invest., 12, Suppl. 54 (The elimination of uric acid in man studied by means of $\mathrm{C}^{\mathbf{1 4}}$-labeled uric acid).

(1962). Arch. intern. Med., 109, 379 (The pathogenesis of gout). 
Les études du pool d'acide urique et ses taux de déplacement

\section{RÉSUMÉ}

Les pools échangeables et le taux de déplacement d'acide urique ont été déterminés chez dix-neuf sujets, certains d'entre eux atteints de goutte, en employant l'acide urique marqué par le $\mathrm{C}^{14}$.

Dans certains cas une amélioration significative et précise dans le nombre d'accès a été obtenue en décrivant des courbes d'élimination d'acide urique radio-actif urinaire avec une fonction bi-exponentielle plutôt qu'avec une fonction mono-exponentielle. Dans de tels cas, il est suggéré que les urates peuvent exister dans un second dépôt physiologique, peut-être en relation à la surface des tophi ou des micro-tophi cristallins. Un malade montrait une courbe bi-exponentielle avant le traitement et une courbe mono-exponentielle 9 mois après avoir commencé un traitement avec l'allopurinol, impliquant ainsi la disparition d'un second dépôt.

Il y a une relation importante entre la dimension des dépôts et le taux de l'urate sérique et entre le taux de déplacement et l'excrétion de l'urate urinaire.

L'exactitude avec laquelle la dimension des dépôts et le taux de déplacement peuvent être estimés par les quantités trouvées dans le sérum a aussi été étudiée.
Estudios del tamaño del pool de acido urico y promedio de renovación

\section{SUMARIO}

El pool cambiable y el promedio de renovación del ácido úrico han sido determinados en diecinueve sujetos, algunos con gota y otros sin ella, usando ácido úrico identificado con ${ }^{14} \mathrm{C}$.

En algunos casos se obtuvo una mejora en el ajuste, matemáticamente significativa, describiendo las curvas de eliminacón de ácido úrico radiactivo urinario con una función biexponencial, más bien que con una monoexponencial. En tales casos, se sugiere que el urato quizá exista en un segundo pool fisiológico, tal vez en relación a la superficie de tofos o microtofos cristalinos. Un paciente reveló una curva biexponencial antes del tratamiento y una monoexponencial nueve meses después de haber comenzado el tratamiento con alopurinol, sugiriendo la desaparición de un segundo pool.

Existe una relación significativa entre el tamaño del pool y el nivel del urato sérico, y entre el promedio de renovación y la excreción de urato por vía urinaria. También se investigó la precisión con que podría calcularse el tamañodel pool el promedio de renovación, a partir de las medidas del suero. 